\title{
Seafood festivals for local development in Italy and Sweden
}

\author{
Lucia Pizzichini \\ Department of Management, Polytechnic University of Marche, Ancona, Italy \\ Tommy D. Andersson \\ Department of Business Administration, School of Business Economics and Law, \\ University of Gothenburg, Göteborg, Sweden, and \\ Gian Luca Gregori \\ Department of Management, Polytechnic University of Marche, Ancona, Italy
}

Received 14 April 2021 Revised 27 August 2021 1 October 2021 Accepted 3 October 2021

\begin{abstract}
Purpose - The paper focusses on festivals taking place in coastal regions whose central element is seafood. The purpose is to analyse the role of seafood festivals as potential tourist attractions for local development. The decision to focus on coastal areas is based on a perceived knowledge gap regarding the interactions between different sectors of the sea economy.

Design/methodology/approach - Qualitative exploratory case studies of seafood festivals in Italy and Sweden have been performed using an analytical model. The participatory observation methodology contributed to a better understanding of the phenomenon.

Findings - The analysis shows the close relationship between seafood and tourism, and although it takes variable forms, food is a fundamental lever for maritime and coastal tourism and local development. Findings suggest that local food events can help strengthening gastronomic identities, despite there is a different articulation between tradition and marketing in the two countries.

Research limitations/implications - Since this paper represents an exploratory study of five seafood festivals, research needs to be extended and replicated before any findings can be generalized. However, the model is flexible enough to be tested in different food events.

Practical implications - Food events represent a key instrument for the integration of territorial policies in which tourism and food products might be used as strategic instruments for the development of coastal areas. Originality/value - This paper is a first attempt to analyse and compare seafood events, contributing to filling the gap in event literature referring to coastal areas. The model introduced can be used to determine the articulation of tradition-marketing in different food events.
\end{abstract}

Keywords Seafood, Food tourism, Food events, Seafood festivals, Event management

Paper type Research paper

\section{Introduction}

Food is often considered a driver of tourism development in territories whose attractiveness is in crisis or as an alternative element for destinations that cannot benefit from natural or historical resources (Kivela and Crotts, 2006). A definition given by Hall and Sharples (2003, p. 10) describes food tourism as "visitation to primary and secondary food producers, food festivals, restaurants and specific locations for which food tasting and/or experiencing the attributes of specialist food production region are the primary motivating factor for travel". In particular, food festivals could represent essential elements for food tourism development (Getz, 2019) and to increase the value of the tourist experience (Green and Dougherty, 2008; Sims, 2009). The goal of food festivals generally is to promote local food and culture by

(C) Lucia Pizzichini, Tommy D. Andersson and Gian Luca Gregori. Published by Emerald Publishing Limited. This article is published under the Creative Commons Attribution (CC BY 4.0) licence. Anyone may reproduce, distribute, translate and create derivative works of this article (for both commercial and non-commercial purposes), subject to full attribution to the original publication and authors. The full terms of this licence may be seen at http://creativecommons.org/licences/by/4.0/legalcode

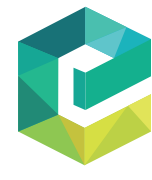

British Food Journal Vol. 124 No. 2, 2022 pp. $613-633$ Emerald Publishing Limited DOI 10.1108/BFJ-04-2021-0397 
$\mathrm{BFJ}$

124,2

614

showcasing and tasting typical food products (Rinaldi, 2017). Moreover, the presence of a food event might increase tourist expenses (Everett and Aitchison, 2008; Kim et al., 2011) and contribute creating a distinctive image, which is essential to influence the choice of a destination and to generate satisfaction. From this perspective, events are "animators of destination attractiveness" (Getz and Page, 2016, p. 593), representing a key marketing proposition to promote a place. The decision to focus attention on the events within the sea economy was based on the growing interest in this sector from businesses, governments and researchers, and on a perceived knowledge gap regarding the interactions between the different sectors that composed the sea economy. In particular, the interactions between tourism and seafood could differentiate the offer, attract visitors looking for more authentic experiences and support sustainable tourism (OECD, 2012). This paper aims to contribute to literature on food events bridging the gap existing between tourism and food sectors in coastal areas, focussing on the role of seafood festivals as potential tourist attractions for local development. Two specific geographic areas were analysed: the Marche region (Italy) and the Västra Götaland region (Sweden). The background analysis concerning EU policy on the sea economy underlines that Italy and Sweden have similar maritime clusters (European Commission, 2012), but at the same time, they have different food and cultural background and approaches. Accordingly, the analysis of seafood festivals in the two countries might contribute both to the literature and to management practices to determine the articulation of tradition-marketing in different food events. The paper is structured as follows: The literature section illustrates the relationship between food and tourism and the role of tradition and marketing in the seafood festivals, with specific insights of Italian and Swedish food culture. Then, the sea economy concept and the seafood and coastal tourism clusters are introduced to understand their main characteristics and connections in the two analysed countries at European level. This is followed by a description of the methodology adopted. The case studies are then described and analysed using a model. The final sections discuss the main findings, implications and suggestions for future research.

\section{Theoretical background}

\subsection{The relationship between food and tourism}

Food and drink are becoming a significant area of interest in the specialized literature on tourism (Boyne et al., 2003; Long, 2004; Mason and Paggiaro, 2012; Xiao and Smith, 2006). Food is fast becoming the basis for different types of tourism, not only those related to gastronomy, because it combines all the requirements to be considered a cultural tourism product (Scarpato, 2002).

Some of the main motivations driving the choice of certain destinations lie in the search for relaxation and physical and psycho-physical well-being, the need for social relations, entertainment and cultural experience. Amongst these factors, the interest in food (Crompton, 1979) plays a crucial role in the tourist experience and might be an opportunity for maximizing economic and regional development benefits (Hall, 2012). Food consumption is a part of tourism, and it has both a direct economic impact on businesses providing food for tourists (such as hotels, restaurants and attractions) and an indirect impact on the food supply chain. In general, connecting tourism to local food might provide potential economic opportunities for the local food businesses, as local gastronomy might become a determining factor in the tourist experience (Hall, 2012). The possibility of tasting food is an integral part of the tourism product (Beer et al., 2002). The whole travel experience is characterized by the decision regarding what and where to taste typical products (wine and food) and might have a decisive role in travellers' motivation (Getz, 2019; Kim et al., 2009; Richards, 2003). In fact, several studies have confirmed the importance of local food for tourists, as it represents a synthesis of the characteristics of a country, highlighting its relation to geography, history, culture 
and people (Bessière, 1998; Hall and Mitchell, 2000, 2006; Hjalager and Corigliano, 2000; Hjalager and Richards, 2002; Rinaldi, 2017). Tikkanen (2007) and Smith and Costello (2009) maintain that local food has recently emerged as a means to attract tourists seeking culinary experiences and new flavour sensations (Gyimóthy and Mykletun, 2009). Therefore, restaurants become not only places to eat but also experiences that could determine the success of the travel experience (Cleaver et al., 1999). Tasting typical local products might be relevant because it is part of the culture and entertainment, and it plays a crucial role in introducing new flavours to tourists. In their study, Lopez-Guzman et al. (2014) underline the role of local food as a resource to promote and advertise a destination, and it could be a "component of the product, which explores the design of gastronomic routes" (Lopez-Guzman et al., 2014, p. 96). Moreover, gastronomy might be considered both a cultural phenomenon and an experience, which could be manifested through the realization of different food events (Jiménez-Beltrán et al., 2016; Lopez-Guzman et al., 2014). Thus, the development of gastronomic tourism depends on the level of connection with the "local culinary culture and with the natural resources of the place where it is settled" (Riley, 2005). Gastronomy plays an important role both in tourist satisfaction and as part of the cultural and environmental heritage of the destination, since tourists buy or consume regional products and often observe and participate in the production of food (Ignatov and Smith, 2006).

\subsection{Seafood festivals between tradition and marketing}

Food tourism might increase the value of the tourist experience (Green and Dougherty, 2008; Sims, 2009) and is becoming a new market niche that seems to contribute to economic and social development, both for rural and coastal areas. Within this context, festivals can be considered a "specific form of tourism that is usually created by the operators, and a festival themed on food and cuisine is defined as a food festival" (Horng et al., 2013, p. 194). However, according to Lee and Arcodia (2011), the presence of food as a component of a festival is not enough to define it as a food festival. A food festival has to be based on local or regional food with activities and programmes related to food. The purpose of these festivals should be to promote local food through the exploration and tasting of typical local dishes. Operators involved in destination marketing activities often use food festivals as a tool to attract tourists and promote the area (Getz, 1991). In fact, destinations need to be competitive offering memorable tourist experiences, but at the same time, preserving their sense of place (Mariani and Giorgio, 2017). The presence of a gastronomic event might increase tourist expenditures (Everett and Aitchison, 2008; Kim et al., 2011), contributing to create a distinctive image, which may be essential to influence the choice of destination. To enhance the positive effects of food festivals, it is crucial for organizers to identify factors that might attract visitors (Smith and Costello, 2009; Yuan and Jang, 2008). Recently, there has been a gradual consolidation of events within food and wine tourism (Getz, 2000), but generally, most of the academic debate and existing research on food events concentrate mainly on rural areas (Hall and Sharples, 2003; Hollows et al., 2013). Therefore, this paper analyses festivals taking place in coastal regions whose central element is seafood, as they contribute creating loyalty to food products and promoting the territory (Mason and Paggiaro, 2009; Simeon and Buonincontri, 2011). Since festivals have all the characteristics of services, especially the intangibility element, visitors pay specific attention to the "festivalscape" (Mason and Paggiaro, 2012; Lee et al., 2017a, b). From a marketing perspective, the festival atmosphere has a strategic function for consumers' satisfaction and reactions because it represents the context in which benefits are produced and consumed (Lee et al., 2008). According to Björk and Kauppinen-Räisänen (2016, p. 177), local food "can be used by service providers, destinations, regions or countries for marketing activities, such as for 
$\mathrm{BFJ}$

124,2

616 restaurant, hotel and destination branding and regional development in general". Therefore, events represent a key element in place marketing to offer a unique proposition that differentiate a destination from competitors (Getz and Page, 2016).

2.2.1 Food culture and food festivals: Swedish and Italian contexts. Food festivals are often linked to ancient regional traditions or significant events in agriculture or fishing, especially in central and southern Europe (Meretse et al., 2015). In coastal areas, seafood festivals often include processions and religious ceremonies for the blessing of the fleet and for profitable fishing (Claesson et al., 2005). In contrast, in New World countries and Nordic European ones, events focus more on marketing and sales, often due to a lack of long tradition and history (Charters and Mitchell, 2014; Hall et al., 2003). The Swedish seafood festivals belong to the latter category, as fishing tends not to be linked to religious or traditional ceremonies. The origin of this dual perspective has been investigated by Fonte (2008) who introduced the concepts of "reconnection" and "origin of food". According to the study, Sweden and other Nordic countries were defined as food deserts, because the only option to buy local food was supermarkets, and there used to be no good small independent local shops and farmers' markets. Therefore, food desert destinations needed to rebuild their food culture and identity through a process of reconnection that reduced the physical distance between producers and consumers to revitalize local communities (Fonte, 2008). A study conducted by the European Union underlines how the Nordic countries developed new culinary experiences by investing in innovation to create unique and engaging seafood events (OECD, 2012). Particular attention was paid to the creation of local food networks to connect the different seafood tourism stakeholders. The festival organizers need to create a positive involvement of stakeholders and to understand their various viewpoints, aims and concerns (Van Niekerk and Getz, 2016; Mariani and Giorgio, 2017). Moreover, stakeholder engagement practices sometimes are necessary to legitimize the festival and to achieve strategic objectives (Van Niekerk and Getz, 2016). In line with the reconnection approach, in 2004, some of the Scandinavian regions' top chefs and food professionals drew up the New Nordic Cuisine Manifesto. It expresses the values on which the New Nordic Cuisine must be based (e.g. popularity, simplicity, freshness and purity) if it wants to make its mark in the world based on its flavours and identity (Nordic Council of Ministers, 2008). Mats Nordström, a Swedish chef, explained the poor image that people have of Swedish food, arguing that "there are not many Swedish restaurants around the world like you have Italian and French restaurants in almost every city in the world [... I I think the image of Swedish food is very high but among people in the industry" (Getz et al., 2015, p. 125). This vision suggests that there is a very positive image of Swedish food amongst connoisseurs abroad but not so much amongst Swedes themselves.

Italy, on the other hand, has an ancient food tradition and is concerned about protecting and enhancing its eno-gastronomic heritage. Differently from the food deserts destinations, in Italy and Mediterranean countries "raw materials, taste and dishes constitute a food tradition and culture that are closely tied to the territorial identity and linked to specific religious or social occurrences and celebrations" (Fonte, 2008, p. 207). Therefore, food is not only an occasion for sociability but a strong element of local identity and culture. This is supported by the emergence of movements like Slow Food and several governmental actions aimed at encouraging the use of labels to show the origin of a food product and its product supply chain. Traditions are deeply rooted in the Italian culture that has a strong image as a food destination, both amongst international and domestic tourists. Recently, UNESCO recognized the role of food and wine festivals as a part of the Italian intangible cultural heritage, as "during festivals, product knowledge is spread among participants and local communities and local products become a powerful tool for disseminating the culture of a place" (Santini et al., 2013, p. 251). Therefore, as shown by Santini et al. (p. 265, 2013), Italian food events are part of the "historical identity of communities" and need to respect some parameters to be called "food festivals (sagra)" (Table 1). 
Although there are no official records of food and wine festivals in Italy, there are approximately 50 seafood festivals every year in the Marche region, which are held by local associations, fishermen's unions, public institutions and private companies (Santini et al., 2013).

Definition: Food and wine festivals are part of the historical identity of communities and towns and should be considered the perfect combination of local authentic cuisines and traditions. Thus, they are the expression of the culture of the territory and their main goals are preservation, dissemination and promotion of cultural heritage. To be "traditional", a festival must have at least a link with the territory that is documented by oral and written tradition, and the programmed cultural activities must reflect the culture and tradition Main role of typical food: The type of food served and the way it is prepared and consumed hint at a community life and a food culture perceived as a sign of identity. The main dishes and recipes should be based on the main ingredients that are promoted through the festivals

Source(s): (Santini et al., 2013)

\subsection{Seafood and coastal tourism clusters}

Currently, the sea economy is one of the largest emerging industries and corresponds to between 6 and $7 \%$ of the European economy. In 2018, the established sectors of the EU Blue Economy directly employed close to 5 million people and generated around $€ 750 \mathrm{bn}$ in turnover and $€ 218 \mathrm{bn}$ in gross value (European Commission, 2020). The EU defined five sectors with high potential opportunities for sustainable blue growth: aquaculture, coastal and maritime tourism, biotechnology, renewable energy, mineral resources and other sectors that are crucial for value and jobs, such as shipbuilding and ship repair, transport, fisheries and offshore oil and gas (European Commission, 2014). All these individual sectors are interdependent, and they rely on common skills and shared infrastructures (Salvador et al., 2015). Within this context, the seafood cluster might include all the activities related to fisheries, aquaculture and mariculture, fish processing and the retail and wholesale of fish. In 2018 , in Italy, the seafood cluster generated a gross added value of $€ 2,631 \mathrm{bn}$ and 73.100 jobs. In Sweden, these sectors have a value of $€ 418 \mathrm{~m}$ and involve 8.200 employees (European Commission, 2020). As part of the sea economy, "the coastal and maritime tourism sector has been identified as an area with special potential to foster a smart, sustainable and inclusive Europe" (European Commission, 2014). Coastal tourism covers beach-based activities and tourism (e.g. swimming, surfing, sunbathing) and land-based tourism in the coastal area as well as the supplier and manufacturing industries associated with these activities. In Italy, the coastal tourism largely dominates the sea economy and contributed $59 \%$ to blue jobs and $45 \%$ to GVA in 2018. The same evidence could be noticed in the Swedish sea economy, with 81.200 employees in the coastal tourism sector and a value of $€ 3,280 \mathrm{~m}$ (European Commission, 2020). Coastal tourism and sea food sectors are part of the sea economy clusters of the two specific regions analysed, Västra Götland (Sweden) and Marche (Italy) (Figure 1).

The data highlighted above show the relevant impact of the sea tourism and seafood sectors in the Swedish and Italian economies. In the fragmented tourism field, the collaboration between different sectors and the creation of networks bridging together multiple stakeholders play an essential role (Mariani and Giorgio, 2017). Therefore, the aim of the study is to investigate the role of seafood events in bringing together the two sectors (seafood and sea tourism) and as potential tourist attractions for local development.

\section{Methodology}

The study uses a qualitative exploratory research approach to describe the phenomenon of seafood festivals, examining five case studies in the Marche region (Italy) and the Västra 
BFJ

124,2

\section{8}

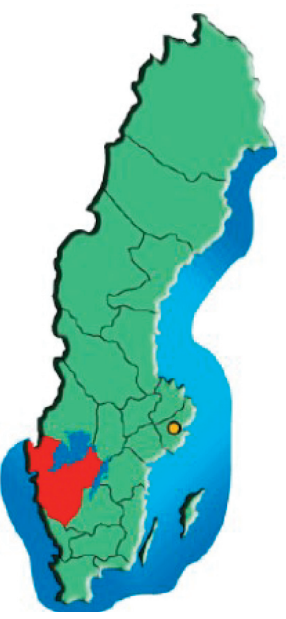

Sea economy clusters in Västra Götland region (Sweden)

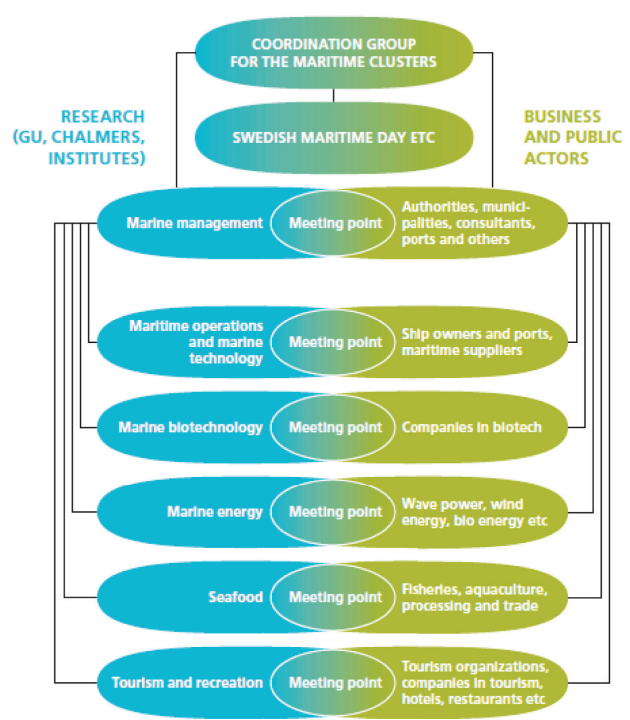

Sea economy clusters in Marche region (Italy)

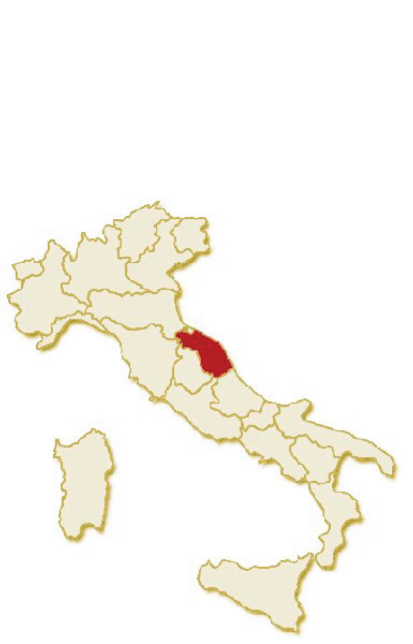

Figure 1.

Sea economy clusters in Västra Götland (Sweden) and Marche (Italy)

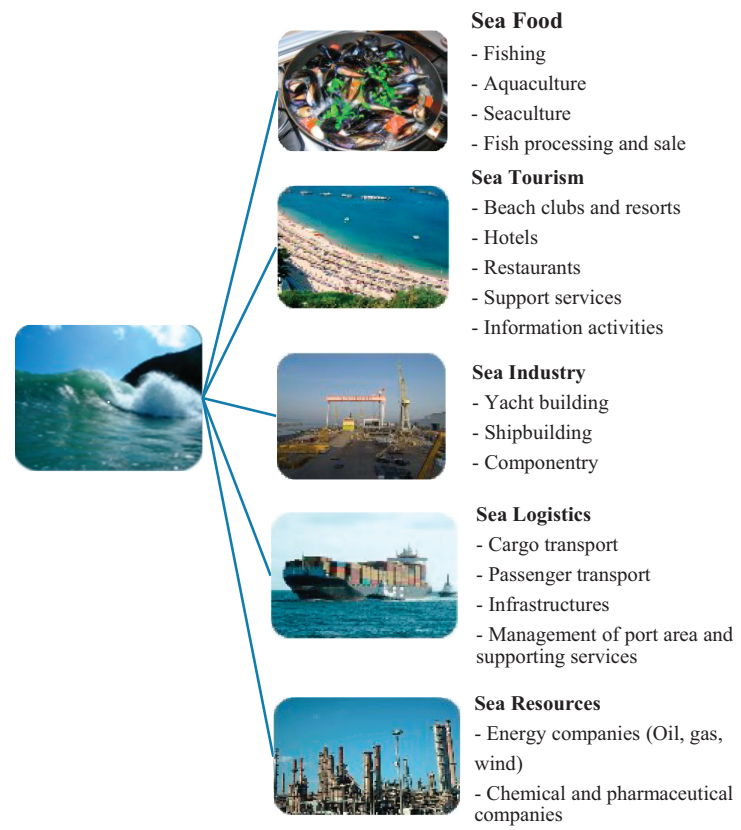


Götaland region (Sweden). Data were collected over three years, from June 2018 to September 2020. At first, the choice to analyse seafood festivals in the Italian and Swedish context was suggested by the review of the literature that highlighted these two countries as representative of a Mediterranean and Scandinavian model in terms of tourism and culinary culture (Meretse et al., 2015; Fonte, 2008; OECD, 2012). Second, Västra Götaland and Marche are coastal regions with similar sectors composing sea economy clusters (cf. Figure 1). The exploratory qualitative approach in the tourism field allows to develop new ideas and to explain the structure of important concepts (Mason et al., 2010; Sarantakos, 2012) and to overcome the critics for the lack of rigorous research methods being used in the event and festival research (Van Niekerk, 2017). The five seafood festivals were selected using convenience sampling, a method used by Lee and Arcodia (2011), to describe the role of regional food festivals for destination branding. The method "allows the researcher to select a requisite number from cases that are conveniently available" (Lee and Arcodia, 2011, p. 358). Table 2. Reports the five case studies analysed in the two regions.

The case study method enables an in-depth investigation of several properties and variables related to the festivals (Yin, 1994, 2017). This methodology allows both for examining different perspectives of a single phenomenon and using multiple detection and data analysis techniques. Moreover, it is consistent with the idea that the research work should include social interactions between the researcher and the object of investigation. The case study approach is recognized as an effective research strategy for exploring the holistic scenarios of local food tourism outcomes in destinations by providing a vital link between theories and practices (Hjalager and Richards, 2002). The literature review of qualitative studies underlined that the participatory observation methodology contributes to an

\begin{tabular}{|c|c|c|}
\hline Festival name & Location & Description \\
\hline $\begin{array}{l}\text { Sill (herring) } \\
\text { festival }\end{array}$ & $\begin{array}{l}\text { Västra Götaland } \\
\text { region (Sweden) }\end{array}$ & $\begin{array}{l}\text { Sill festival is a one-afternoon event, arranged once a year in Tjörn } \\
\text { (June 6). The } 12 \text { th festival was held in } 2019 \text {. The main organizer of } \\
\text { the event is a herring manufacturing company. The } 2020 \text { edition } \\
\text { was held digitally, through live streaming on Facebook }\end{array}$ \\
\hline Musselfest & $\begin{array}{l}\text { Västra Götaland } \\
\text { region (Sweden) }\end{array}$ & $\begin{array}{l}\text { This is a yearly event, arranged for the } 14 \text { th year in } 2019 \text {. It is an } \\
\text { afternoon event starting at } 2 \text { p.m. and arranged in the central park } \\
\text { of a coastal town, Lysekil, in the Swedish county of Bohuslän. The } \\
2020 \text { edition was cancelled due to COVID-19 pandemic }\end{array}$ \\
\hline Oyster festival & $\begin{array}{l}\text { Västra Götaland } \\
\text { region (Sweden) }\end{array}$ & $\begin{array}{l}\text { This is one of the three main shellfish festivals (together with the } \\
\text { Musselfest and the day of the shrimp) that takes place annually } \\
\text { along the west coast of Sweden. In } 2019 \text {, the 15th festival took } \\
\text { place. The oyster academy played an important role in the } \\
\text { establishment of the festival } \\
\text { The festival occurred in September in Grebbestad. The } 2020 \\
\text { edition was cancelled due to COVID-19 pandemic }\end{array}$ \\
\hline Anghió & Marche region (Italy) & $\begin{array}{l}\text { Anghió is a yearly bluefish festival. In 2018, the 9th festival } \\
\text { occurred for a week in September and moved from San Benedetto } \\
\text { del Tronto to Porto Sant'Elpidio. Both cities lie on the coast of the } \\
\text { Adriatic sea and are active fishing ports. San Benedetto del } \\
\text { Tronto is one of the main seaside resorts on the central Adriatic } \\
\text { coast. In } 2020 \text { the festival was held in September } 9-13\end{array}$ \\
\hline Tipicitá in blu & Marche region (Italy) & $\begin{array}{l}\text { This is an annual event that occurs in September-October; the 7th } \\
\text { festival was on 10-11 October 2020, in Ancona (the capital of the } \\
\text { region), and it lasts two days. It is a spin-off focussed on the } \\
\text { seafood of Tipicitá, which is a yearly event that occurs in the } \\
\text { hinterland }\end{array}$ \\
\hline
\end{tabular}

Source(s): Authors' elaboration

Table 2.

The seafood festivals investigated in the study 
$\mathrm{BFJ}$

124,2

620

understanding of the phenomenon with an "insider point of view", and it allows researchers to take part in local social life (Mariani and Giorgio, 2017). Therefore, participant observation of the five seafood festivals was conducted by the authors themselves using field notes, photographs and maps included in a report. Moreover, to understand the major managerial and organizational features of the festivals, informal conversations as well as in-depth interviews with the Director and Coordinator of the organizing committee of the two most representative seafood festivals in each region (the Anghió festival in Italy and the Mussel Festival in Sweden) were carried out. Each interview was conducted in person, using the local language of interviewees (Italian and Swedish) to facilitate the interaction and lasted between 1.30 and $2 \mathrm{~h}$. Researchers recorded all interviews and transcribed and accurately translated them into English. To deal with the ethical aspects (Malhotra et al., 2017), sensitive and personal data of interviewed people are known only by the researchers who gave accurate information on the purpose of the research. Moreover, before the interview participants, were asked to give permission to record. The five case studies were described and analysed using an analytical model based on four perspectives, which are directly or indirectly connected with the core elements of food and tradition. The four dimensions are local food, restaurant involvement, food markets and petty trade and entertainment (Figure 2).

The model is based on an analysis of the existing literature on food festivals (Andersson and Mossberg, 2017; Björk and Kauppinen-Räisänen, 2016; Getz et al., 2015; Mason and Paggiaro, 2009, 2012; Dimitrovski, 2016; Lee and Arcodia, 2011; Ab Karim and Chi, 2010; Axelsen and Swan, 2009; Yuan and Jang, 2008), and it is designed with the objective of identifying the main dimensions guiding the observation process and emerging from the events' organizers interviews. The aim was to explore the role of food and non-food variables (Dimitrovski, 2016) in the staging of Italian and Swedish seafood festivals to investigate the role of tradition and marketing.

Figure 2.

Model used to analyse the main dimensions of food festivals

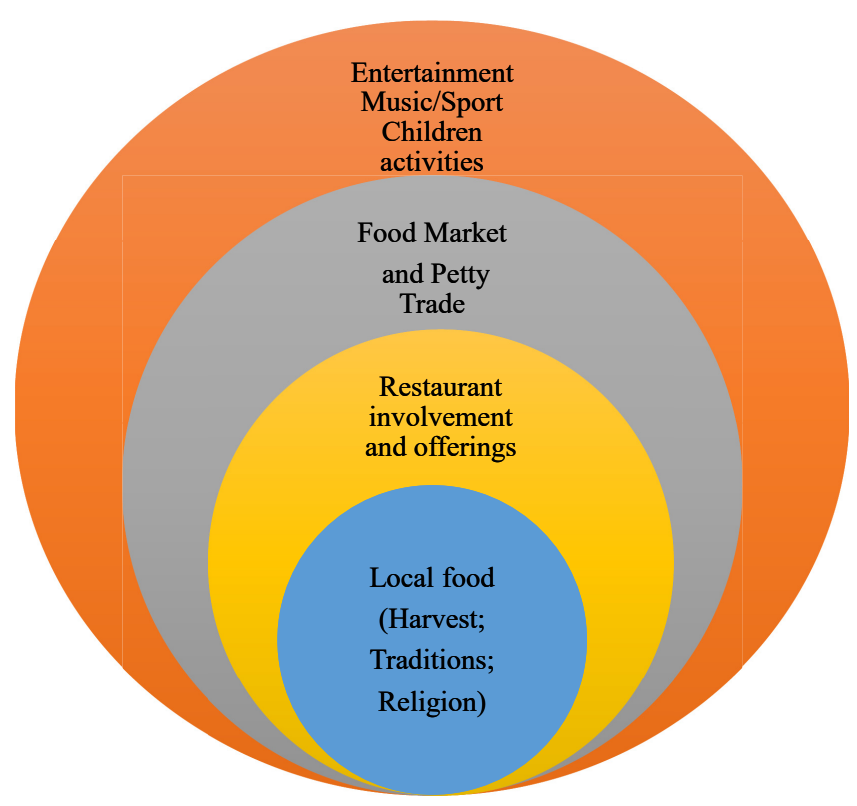

Source(s): Authors' elaboration 


\section{Results}

The first element emerging from the analysis of the five case studies is the differences between Italian and Swedish seafood festivals in terms of festival length and choice of location. While the seafood festivals in the Marche region lasted several days in the main coastal cities (Ancona is the capital of Marche region, and San Benedetto del Tronto is the fifth most populated city in the region), the Västra Götaland events are mostly held in small fishing villages and last only half a day. The characteristics of the seafood festivals were investigated by focussing on the four pillars of the model, local food, restaurant involvement, food market and petty trade and entertainment (cf. Figure 2), and they are summarized in Table 3 .

\subsection{Local food}

Food establishes immediate and direct contact with the culture and tradition of a place (Heldke, 2015; Robinson and Clifford, 2012). Food locally produced means that it takes origin from a specific area that differentiates it from the other products. Therefore, local food has an intangible heritage that allows tourists to be in contact with the local culture and traditions contributing to the destination marketing and development (Folgado-Fernández et al., 2016; Rinaldi, 2017). Food presented in the investigated festivals was regionally sourced from local fisheries, with some specific differences. In the Swedish festivals, a lack of attention to local food and variety was noted, with the exception of the Oyster festival that had a strong focus on food, and visitors mainly attended the festival to savour oysters. The restaurant tent was very busy during the $5 \mathrm{~h}$ of the festival (12.00-17.00), and many visitors also sat on the dockside with a plate of oysters and a glass of champagne. Apart from champagne to go with the oysters, the local brewery presented a beer named the Oyster porter. However, only one choice of food was available (i.e. raw oysters with lemon zests), and there were no inspirational demonstrations of alternative ways to enjoy the food. The research reveals the same results for the Mussel and Herring Festivals, where there was no opportunity to discover new ways of savouring the seafood, and the main seafood characterizing each event was also an industrial food product which was produced by the companies organizing and sponsoring the event (Figure 3). As stated in the theoretical background analysis, it is not enough to have local food in a festival, but it has to be promoted through the exploration and tasting of typical local dishes to create an experience (Lee and Arcodia, 2011).

The seafood festivals investigated in the Marche region were focussed on savouring the food as the main attraction for visitors. Data collected from interviews with organizers show that during the Anghió festival approximately 20 quintals of bluefish (a typical local species from the Adriatic Sea) were eaten, and 50,000 dishes were prepared. The great attention to the food allowed the organizers to develop the festival into an emotional trip to discover the bluefish through tradition and innovation. The events are characterized by the variety of dishes and the involvement of local and international chefs who elaborate gourmet recipes with traditional products (Figure 4).

Another distinctive difference of Italian seafood festivals compared to the Swedish ones in terms of local food concerns the collaboration with local wineries and the pairing of wine with food. Several studies underlined the importance of wine offer and tasting in tourists' evaluation of seafood events (Getz, 2016; Crotts et al., 2008). While in Italy, there was a beverage offer in all investigated festivals, in Sweden only the Oyster Day offered a pairing with a special brewed beer.

\subsection{Restaurant involvement}

The restaurants' programmes were directly connected with the importance of food within the festivals. Therefore, the analysis revealed that the Oyster festival in the Västra Götaland 
$\mathrm{BFJ}$

124,2

622

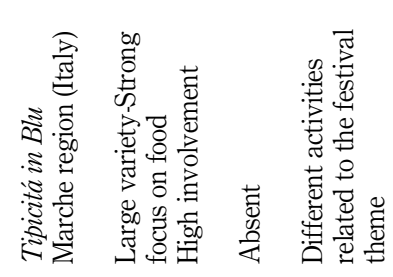

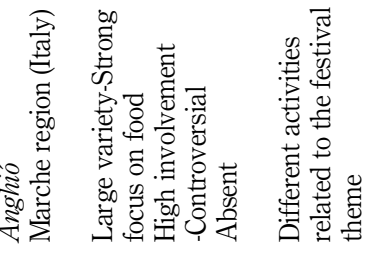

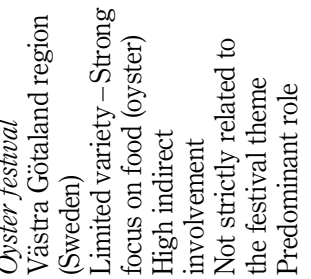

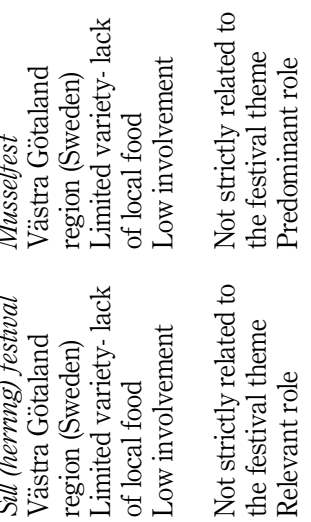

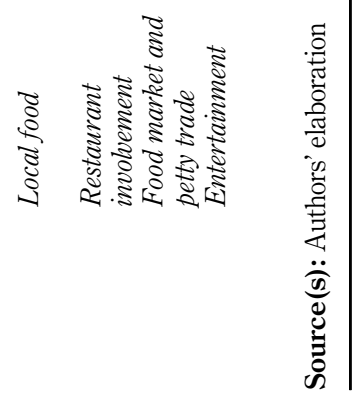

Table 3.

Similarity and

differences between the investigated seafood festivals 


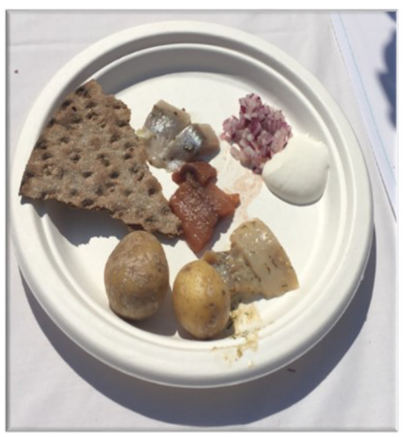

Source(s): Authors' elaboration

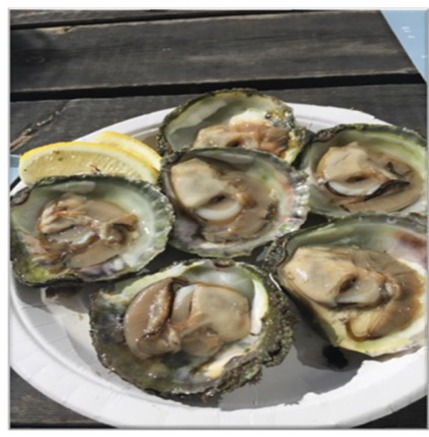

Seafood festivals

623

Figure 3.

Seafood presentation in Västra Götland (Sweden) festivals

region had a dozen restaurants along the boardwalk in the marina showing menus inspired by the oyster theme. These restaurants were very busy during the lunch hours, and some of them had set up tents to accommodate more guests. Informal interviews conducted during the day indicated that "the Oyster Day often is the best day of the year for the restaurants along the dockside". In contrast, the restaurants were not much involved in the Mussel Festival and were not involved in the Herring Festival at all.

In Italy, there were debates amongst the Anghió organizers related to restaurant involvement. During the first editions of the festival, restaurateurs were more engaged and tended to introduce a special menu during the festival days. However, after the first two editions, local restaurateurs argued that the festival took away customers from their restaurants. Therefore, the organizers tried to directly involve the restaurateurs in the festival as special guests or by promoting some of the dishes of local restaurants in the festival menu.

During the first editions of the festivals we had an agreement with the Restaurateurs' Associations to involve them during the event by promoting specific menus. At first there was a positive response, but later discussions and discontent began, so we decided to not continue the collaboration. However, we tried to involve in a different way the single restaurateur who wanted to take part in the event. M.P. - Director of Anghió festival organizing committee

Restaurants are one of the different stakeholder categories that festival organizers have to manage and to create a positive engagement, if they want the event succeed (Van Niekerk and Getz, 2016). The restaurants are the main participants in Tipicitá in Blu. During the festival, 48 local restaurants propose a blue menu, and 37 bars have an aperitif with seafood products.

\subsection{Food market and petty trade}

Small shops and markets could represent significant elements to support the dissemination of knowledge of local products and promote activities accordingly. Through the purchase of local food products, visitors establish a closer bond to the place and producers and keep memories of different countries and cultures (Pizzichini et al., 2020). However, in the cases observed, there was a lack of attention concerning this aspect. In particular, there was a total absence of food markets and markets in general in Italian festivals, which highlights the predominance of the central core of the model, where food, its presentation and consumption play the main role. This, on the one hand, might represent a lack of openness to other activities that could help to make products better recognized by the public and attract tourists at a later time. On the other hand, this approach highlights the Italian attitude towards the predominance of tradition over marketing. 
BFJ

124, 2

624
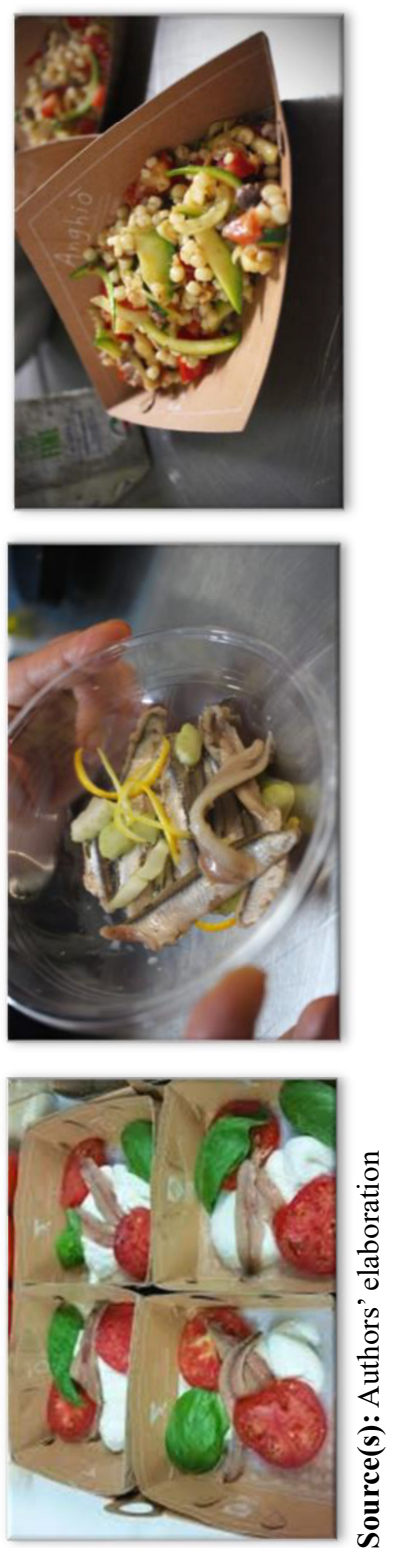

Figure 4.

Seafood presentation in

Marche (Italy) festivals 
In contrast, in all the Swedish seafood festivals investigated, there were opportunities to buy also a large variety of goods unrelated to seafood. There was petty trade with stands selling clothes, handicrafts, fruit, vegetables, cheese, toys and candies. It is evident that the organizers were attempting to attract tourists by focussing on a wider array of shopping activities (Mason and Paggiaro, 2012) in addition to those specifically related to seafood.

We have a large number of tents selling all kinds of goods from clothes to sweets, but we would like to develop this part to include more local food and crafts and less of the general market.

R.K. - Director of Musselfest organizing committee

As it emerged in the interviews, this approach might have a negative impact on place identity and the tourists' perception of food authenticity. Several studies found that local origin and authenticity of food products are important factors for tourists who desire to explore the local culture, to obtain unique products and to contribute to the local community development (Pizzichini et al., 2020; Altintzoglou et al., 2016; Sims, 2009; Sthapit, 2018).

\subsection{Entertainment}

Entertainment was an important element to attract visitors in the Swedish seafood festivals. It played a predominant role especially in the Mussel and Oyster festivals; in particular, running sports events complemented the food festivals. During the Mussel Festival, there was a $10 \mathrm{~km}$ running race with several international runners and almost 1,000 local amateur runners. The race passed close to the central park where the food festival occurred and attracted many visitors. In contrast, the sport event held during the Oyster festival did not have a direct impact on the festival because the race started and terminated at the sponsoring sport equipment outlet, which was $5 \mathrm{~km}$ from the festival. The third Swedish festival had less of an emphasis on running sport events but included sailing competitions. Another activity belonging to the entertainment dimension is music concerts: There were music concerts held during the Mussel, the Herring and the Oyster festivals in Sweden. The Italian seafood festivals organized different activities, not strictly culinary, to involve and to introduce bluefish to visitors. During the festivals, conferences and meetings were held with topics focussed both on development opportunities for the fishing sector and on the promotion and development of local products. Similarly, fishing tours with local fishermen contributed to creating experiences for tourists. Some educational activities were organized during the Oyster festival to teach oyster opening skills and to present research results about the history of oyster fishing as well as current oyster aquaculture. The presence of different activities within the seafood festivals contributes to local development, offering an opportunity of entertainment and feast (Mason and Paggiaro, 2012). Another element related to entertainment is the children's activity. In the Swedish festivals, different initiatives were arranged, such as a painting area sponsored by the Nordic Watercolour Museum of Skärhamn during the Herring Festival or a carousel and a giant inflated plastic slide for children to play with at the Musselfest. In the Italian festivals, there were no specific activities directed towards kids, except that the Anghio festival area was located next to a park with children's games that had been placed also on the beach.

\section{Discussion}

\subsection{Research and theoretical contributions}

The qualitative research on seafood festivals in the Västra Götaland and in the Marche regions was performed to understand the role these events play for local development. From a 
$\mathrm{BFJ}$

124,2

626 theoretical point of view, this paper is a first attempt to fill the gap in the literature on seafood and tourism in the under-investigated context of coastal areas, and a first understanding of how different clusters of the sea economy - seafood and sea tourism - are connected is provided. Several studies highlighted the increasing interest of Destination Marketing Organizations (DMOs) in linking a destination with food events, as they contribute to building a culinary image and transforming a destination into a place of gastronomy (Horng and Tsai, 2010; Lee and Arcodia, 2011; Yang et al., 2020). In fact, findings suggest that despite the uniformity of maritime clusters and the strong relation between seafood and maritime tourism, seafood festivals are strongly influenced by cultural elements (Getz and Robinson, 2014). The different food culture appears to be reflected also on the staging of the festivals influencing the articulation of tradition and marketing of different food events.

These differences are reflected in the four dimensions investigated (Figure 5).

The core of the model describes how food festivals celebrate local traditions and harvests which might have begun with a religious significance, particularly in the Italian/ Mediterranean context. The second level indicates that the festival and the celebration of tradition are not limited to the festival per se but could also engage local restaurants, extending the food celebration experience to other facilities. The food markets and petty trade might offer another way of engaging consumers and tourists. Petty trade may attract visitors who perhaps are not so interested in the food festival per se but might want to attend the event for more generic leisure motives (Getz, 2019). On the other hand, petty trade might negatively affect the perception of the authenticity of the event (Pizzichini et al., 2020; Altintzoglou et al., 2016; Sims, 2009).

Figure 5 illustrates how Italian seafood festivals are based on local food and built on traditions whereas Swedish seafood festivals seem to be based on entertainment and shopping activities and seafood experiences appear to be an "add-on". Sweden belongs to "food deserts" countries, but it appears to also try to reconnect with its culture and identity

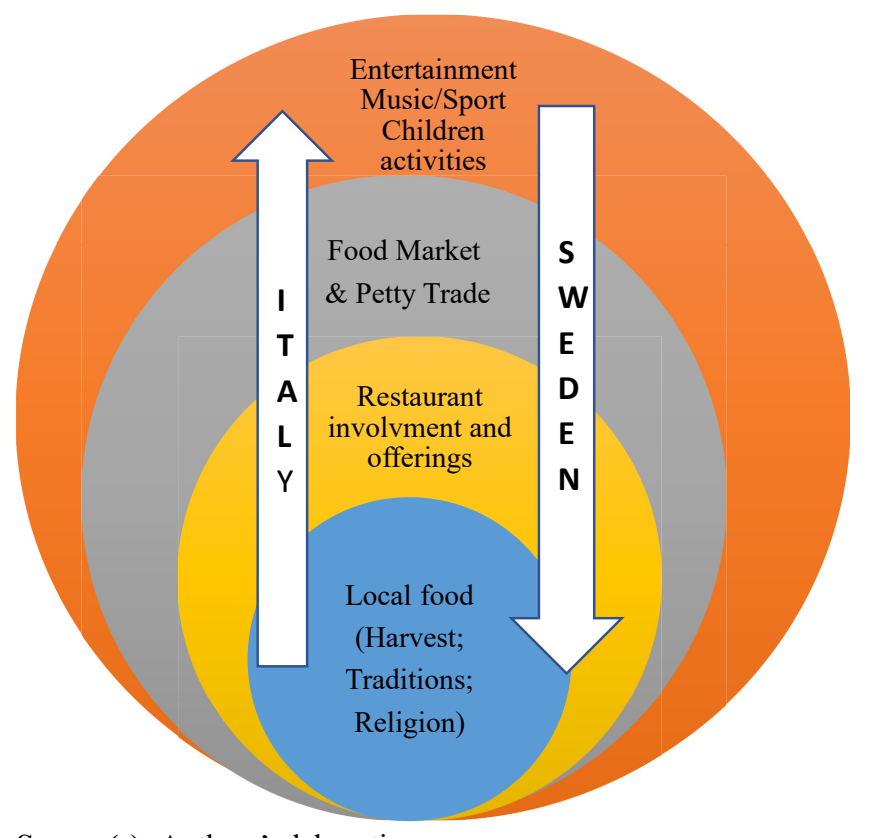

Source(s): Authors' elaboration
Figure 5.

Different approaches of Italian and Swedish seafood festivals 
(Fonte, 2008) using food festivals to reconstruct and rediscover food traditions. Throughout the years, food knowledge was almost lost and it now needs to be rebuilt through experience exchange between different actors. Food needs to be re-spatialized and re-socialized, and food festivals can establish direct contact between producers and consumers based on trust and reciprocal benefits (Fonte, 2008). Scandinavian people are rediscovering the significance of their local food and lost traditions. The Västra Götaland region is promoting itself as a food tourism destination based on local products such as seafood (shrimp, crayfish, oysters, mussels and herring), as showed by the Musselfest coordinator interviewed:

The Mussel Academy was formed in 2006 to give the mussel a larger place on the dining table and in the restaurants' menus. Amongst the event promoters there are researchers, chefs and mussel farmers that saw opportunities to provide healthy and delicious food, and to stimulate a new business.

F.G. - Coordinator of Musselfest organizing committee

Local food is the core element in the Italian seafood festivals. The background analysis showed that Italy belongs to the "origin of food" countries, where the local and traditional knowledge on how to produce, grow and prepare food is part of the local culture (Fonte, 2008). Restaurant involvement seems to be similar in the two countries studied with an interesting exception of Italian restaurants in San Benedetto protesting against unfair competition from the seafood festival. To achieve the goal of destination branding, it is necessary to implement the collaboration and coordination between different actors involving them from the early stage of the festival planning (Mariani and Giorgio, 2017). In this way, organizers can legitimize the festival understanding different stakeholder needs and viewpoints (Van Niekerk and Getz, 2016). From a destination branding perspective, some inconsistencies are highlighted as well. In fact, Swedish seafood festivals are led by marketing and place development reasons, but there is a lack of communication. As stated by Mariani and Giorgio (2017), the destination branding process consists of brand identity, image and positioning. Without proper marketing communication activities, there is a risk that coherence is not recognized between the brand identity and the brand image. The main results from search engines related to the Mussel Festival concerned the Marathon race that occurs during the event and the website is dedicated to the Mussel academy (http://musselakademien.se/). Similarly, for the Oyster festival, there is no information available about the event, and only information related to the permanent academy and seafood per se is retrievable (https:// ostronakademien.se/). For tourists who want to participate in the Swedish festivals, it is not easy to find information. On the contrary, both the Anghio festival (www.anghio.it) and the Tipicitá in Blu (https://www.tipicitainblu.it/) have easily accessible webpages; moreover, some weeks before the events take place, the organizers distribute advertising posters around neighbouring cities.

The overall analysis shows the close relationship between seafood and tourism, and although it takes variable forms, food festivals and events appear to contribute to local development by attracting tourists and by raising awareness of the place "as a destination by showcasing its local food" (Lee and Arcodia, 2011; Rinaldi, 2017, p. 8). Moreover, the interviews and the observation process showed that food tourism in coastal areas needs to manage specific issues related to sustainability. In fact, while the consumption of local food supports the local economy and might reduce the carbon footprint (Rinaldi, 2017), the seasonality and the environmental issues need to be addressed. Furthermore, the response capacity is limited to a fragmented and uncoordinated sector, and a structural lack of skills is limiting innovation and access to resources. Therefore, it is fundamental that all the stakeholders have expertise and knowledge about how to use food in destination marketing since the local food is one of the main elements of the destination intangible heritage (Okumus et al., 2007). 
$\mathrm{BFJ}$

124,2

\section{Conclusions and future research}

\subsection{Managerial implications}

Food tourism is a resource for the socioeconomic development of a territory, including coastal areas. This study shows how local seafood festivals can be used as a marketing activity for food producers, restaurants and hotels as well as for destination branding and regional development in general (Björk and Kauppinen-Räisänen, 2016). The model presented contributes to give an overview of the sea economy as a whole where food led to establishing an immediate and direct connection with the culture and tradition of a place (Okumus, 2007; Robinson and Clifford, 2012). Moreover, food events might represent a key instrument for the integration of territorial policies in which tourism and food products might be used as strategic tools (Marchini et al., 2015) for the development of coastal areas.

The research shows how the management of seafood festivals, analysed through the four dimensions of local food, restaurant involvement, food markets and petty trade and entertainment, allows an integral management of the coastal resources and gives opportunities to promote locally produced food (Katila et al., 2019). The model developed in the study shows how the integration between the different dimensions can have a multiplying effect and allows to analyse the articulation between marketing and tradition for an integrated place development. In this way, the local products can be showcased not only to highly involved food consumers (foodies) (Getz et al., 2015; Robinson and Getz, 2014) but also to tourists who only casually attend the festival. The analysis of the Italian and Swedish seafood festivals indicate that Swedish festivals might need to enhance the local food culture, whereas Italian seafood festivals may have growth potentials in terms of entertainment and shopping activities to increase visitor numbers and economic impact of events. Based on the analysis, seafood festivals in Italy could be further improved by strengthening the lateral networking with local markets and small retailers (cf. Figure 5). Indeed, the collaboration and coordination amongst the different actors both in the public sphere and in the private sector is crucial for destination marketing and management (Mariani et al., 2014). Seafood festivals can contribute to local development and to build destination value if the events' organizers are able to balance the social and economic aspect of festival management. From an economic perspective there is a need to promote foods and brands of the destination, while from the social one, it is important to create local residents' enjoyment, preserve local traditions and contribute to tourists' learning. Food tourism can help strengthening a place's gastronomic identity even further (Andersson and Mossberg, 2017), but event managers should consider that placing a great deal of attention on marketing activities beyond the focus of the festival could make a festival appear less authentic and thus generate distrust in tourists who are looking for authenticity.

\subsection{Limitations and future research}

This study supports the argument that seafood festivals might contribute to the development of coastal areas and increase knowledge and interest in local seafood and its traditions. Since this paper represents an exploratory study of five seafood festivals, research needs to be extended and replicated before any findings can be generalized (Lee and Arcodia, 2011). However, the model presented is flexible enough to be applied to different cultural and geographical contexts. Future research could consider quantitative approaches to explore the role of seafood festivals from the perspectives of various stakeholders (Van Niekerk and Getz, 2016) such as visitors, tourist agencies, restaurants and food producers and analyse seafood festivals in countries other than Sweden and Italy.

The current situation caused by the spread of COVID-19 virus significantly affects all sectors of the sea economy in Europe. Also, food events were forced to stop or to change the format during 2020 and 2021. Swedish and Italian governments adopted very diverse 
approaches to face the pandemic leading to a different impact on the economy of the two countries. Therefore, future research could be developed to analyse the impact of the different government actions on seafood events in the two countries. Moreover, the management model adopted by food event managers to face the challenges of social distancing and the lack of tourists should be investigated.

\section{References}

Ab Karim, S. and Chi, C.G.Q. (2010), "Culinary tourism as a destination attraction: an empirical examination of destinations' food image", Journal of Hospitality Marketing and Management, Vol. 19 No. 6, pp. 531-555, doi: 10.1080/19368623.2010.493064.

Altintzoglou, T., Heide, M. and Borch, T. (2016), "Food souvenirs: buying behaviour of tourists in Norway", British Food Journal, Vol. 118 No. 1, pp. 119-131.

Andersson, T.D. and Mossberg, L. (2017), "Travel for the sake of food", Scandinavian Journal of Hospitality and Tourism, Vol. 17 No. 1, pp. 44-58, doi: 10.1080/15022250.2016.1261473.

Axelsen, M. and Swan, T. (2009), "Designing festival experiences to influence visitor perceptions: the case of a wine and food festival”, Journal of Travel Research, Vol. 49 No. 4, pp. 436-450, doi: 10. 1177/0047287509346796.

Beer, S., Edwards, J., Fernandes, C. and Sampaio, F. (2002), "12 Regional food cultures: integral to the rural tourism product?", in Hjalager, A.M. and Richards, G. (Eds), Tourism and Gastronomy, Routledge, London, pp. 207-223.

Bessière, J. (1998), "Local development and heritage: traditional food and cuisine as tourist attractions in rural areas", Sociologia Ruralis, Vol. 38 No. 1, pp. 21-34.

Björk, P. and Kauppinen-Räisänen, H. (2016), "Local food: a source for destination attraction", International Journal of Contemporary Hospitality Management, Vol. 28 No. 1, pp. 177-194, doi: 10.1108/ijchm-05-2014-0214.

Boyne, S., Hall, D. and Williams, F. (2003), "Policy, support and promotion for food-related tourism initiatives", Journal of Travel and Tourism Marketing, Vol. 14 No. 3, pp. 131-154, doi: 10.1300/ J073v14n03_08.

Charters, S. and Mitchell, R. (2014), "Food and wine events in Europe and the new world", Cavicchi, A. and Santini, C. (Eds), Food Wine Events in Europe: A Stakeholder Approach, Routledge, London, pp. 41-53.

Claesson, S., Robertson, R.A. and Hall-Arber, M. (2005), "Fishing heritage festivals, tourism, and community development in the Gulf of Maine", in, Peden, J.G. and Schuster, R.M., (Eds), Proceedings of the 2005 Northeastern Recreation Research Symposium, April 10-12, Bolton Landing, NY, Gen. Tech. Rep. NE-341, US Forest Service, Northeastern Research Station, Newtown Square, Pennsylvaniya, PA, pp. 420-428.

Cleaver, M., Muller, T.E., Ruys, H.F. and Wei, S. (1999), "Tourism product development for the senior market, based on travel-motive research”, Tourism Recreation Research, Vol. 24 No. 1, pp. 5-11.

Crompton, J.L. (1979), "Motivations for pleasure vacation”, Annals of Tourism Research, Vol. 6 No. 4, pp. $408-424$.

Crotts, C., Pan, B. and Raschid, A. (2008), "A survey method for identifying key drivers of guest delight”, International Journal of Contemporary Hospitality Management, Vol. 20 No. 4, pp. 462-470.

Dimitrovski, D. (2016), "Urban gastronomic festivals-non-food related attributes and food quality in satisfaction construct: a pilot study", Journal of Convention and Event Tourism, Vol. 17 No. 4, pp. 247-265, doi: 10.1080/15470148.2015.1136978.

European Commission (2012), Blue Growth: Opportunities for Marine and Maritime Sustainable Growth, Communication from the Commission to the European Parliament, the Council, the European Economic and Social Committee and the Committee of the Regions, Publications Office of the European Union. doi: 10.2771/43949. 
$\mathrm{BFJ}$

124,2

630

European Commission (2014), "Innovation in the Blue Economy: realising the potential of our seas and oceans for jobs and growth", 13.5.2014 $\operatorname{COM(2014)~Final/2,~pp.~1-10,~available~at:~https:/ec.~}$ europa.eu/maritimeaffairs/policy/blue_growth_en.

European Commission (2020), The EU Blue Economy Report. 2020, Publications Office of the European Union, Luxembourg, available at: https://ec.europa.eu/maritimeaffairs/sites/ maritimeaffairs/files/2020_06_blueeconomy-2020-ld_final.pdf.

Everett, S. and Aitchison, C. (2008), "The role of food tourism in sustaining regional identity: a case study of cornwall, south west england", Journal of Sustainable Tourism, Vol. 16 No. 2, pp. 150-167, doi: 10.2167/jost696.0.

Folgado-Fernández, J.A., Hernández-Mogollón, J.M. and Duarte, P. (2016), "Destination image and loyalty development: the impact of tourists' food experiences at gastronomic events", Scandinavian Journal of Hospitality and Tourism, Vol. 1 No. 19, doi: 10.1080/15022250.2016. 1221181.

Fonte, M. (2008), "Knowledge, food and place. A way of producing, a way of knowing", Sociologia Ruralis, Vol. 48 No. 3, pp. 200-222.

Getz, D. (1991), Festivals, Special Events, and Tourism, Van Nostrand Reinhold, New York, NY.

Getz, D. (2000), Explore Wine Tourism: Management, development \& destinations, Cognizant Communication Corporation, New York, NY.

Getz, D. (2019), "Wine and food events: experiences and impacts", in Sigala, M. and Robinson, R.N. (Eds), Wine Tourism Destination Management and Marketing, Palgrave Macmillan, Cham, pp. 143-164.

Getz, D. and Page, S.J. (2016), "Progress and prospects for event tourism research", Tourism Management, Vol. 52, pp. 593-631.

Getz, D. and Robinson, R.N. (2014), "Foodies and food events", Scandinavian Journal of Hospitality and Tourism, Vol. 14 No. 3, pp. 315-330.

Getz, D., Andersson, T., Vujicic, S. and Robinson, R.N. (2015), "Food events in lifestyle and travel", Event Management, Vol. 19 No. 3, pp. 407-419, doi: 10.3727/152599515x14386220874968.

Green, G.P. and Dougherty, M.L. (2008), "Localizing linkages for food and tourism: culinary tourism as a community development strategy", Community Development, Vol. 39 No. 3, pp. 148-158.

Gyimóthy, S. and Mykletun, R.J. (2009), "Scary food: commodifying culinary heritage as meal adventures in tourism", Journal of Vacation Marketing, Vol. 15 No. 3, pp. 259-273, doi: 10.1177/ 1356766709104271.

Hall, C.M. (2012), "Boosting food and tourism-related regional economic development", Food and the Tourism Experience: the OECD-Korea Workshop, OECD Studies on Tourism, pp. 49-62.

Hall, C.M. and Mitchell, R. (2000), "Wine tourism in the Mediterranean: a tool for restructuring and development”, Thunderbird International Business Review, Vol. 42 No. 4, pp. 445-465.

Hall, C.M. and Mitchell, R. (2006), "Gastronomy, food and wine tourism”, in Buhalis, D. and Costa, C. (Eds), Tourism Business Frontiers: Consumers, Products and Industry, Butterworth-Heinemann, Oxford, pp. 137-147.

Hall, C.M. and Sharples, L. (2003), "The consumption of experiences or the experience of consumption? An introduction to the tourism of taste", in Hall, C.M., Sharples, L., Mitchell, R., Macionis, N. and Cambourne, B. (Eds), Food Tourism Around the World, Routledge, New York, NY, pp. 1-24.

Hall, C.M., Sharples, L., Michell, R., Macionis, N. and Cambourne, B. (2003), Food Tourism Around the World, Butterworth-Heinemann, Oxford.

Heldke, L. (2015), Exotic Appetites: Ruminations of a Food Adventurer, Routledge, London.

Hjalager, A.M. and Corigliano, M.A. (2000), "Food for tourists - determinants of an image", International Journal of Tourism Research, Vol. 2 No. 4, pp. 281-293.

Hjalager, A.M. and Richards, G. (2002), Still undigested: research issues in tourism and gastronomy, in Hjalager, A.M. and Richards, G. (Eds), Tourism and Gastronomy, Routledge, London, pp. 224-234. 
Hollows, J., Jones, S., Taylor, B. and Dowthwaite, K. (2013), "Making sense of urban food festivals: cultural regeneration, disorder and hospitable cities", Journal of Policy Research in Tourism, Leisure and Events, Vol. 6 No. 1, pp. 1-14, doi: 10.1080/19407963.2013.774406.

Horng, J.S. and Tsai, C.T.S. (2010), "Government websites for promoting East Asian culinary tourism: a cross-national analysis”, Tourism Management, Vol. 31 No. 1, pp. 74-85.

Horng, J.S., Su, C.S. and So, S.I.A. (2013), "Segmenting food festival visitors: applying the theory of planned behavior and lifestyle", Journal of Convention and Event Tourism, Vol. 14 No. 3, pp. 193-216.

Ignatov, E. and Smith, S. (2006), "Segmenting Canadian culinary tourists", Current Issues in Tourism, Vol. 9 No. 3, p. 235.

Jiménez-Beltrán, F.J., López-Guzmán, T. and González Santa Cruz, F. (2016), "Analysis of the relationship between tourism and food culture", Sustainability, Vol. 8 No. 5, p. 418.

Katila, J., Ala-Rämi, K., Repka, S., Rendon, E. and Törrönen, J. (2019), "Defining and quantifying the sea-based economy to support regional blue growth strategies-case Gulf of Bothnia”, Marine Policy, Vol. 100, pp. 215-225.

Kim, Y.H., Yuan, J., Goh, B.K. and Antun, J.M. (2009), "Web marketing in food tourism: a content analysis of web sites in west Texas", Journal of Culinary Science and Technology, Vol. 7 No. 1, pp. 52-64, doi: 10.1080/15428050902788352.

Kim, Y.H., Kim, M. and Goh, B.K. (2011), “An examination of food tourist's behavior: using the modified theory of reasoned action”, Tourism Management, Vol. 32 No. 5, pp. 1159-1165, doi: 10. 1016/j.tourman.2010.10.006.

Kivela, J. and Crotts, J.C. (2006), "Tourism and gastronomy: gastronomy's influence on how tourists experience a destination”, Journal of Hospitality and Tourism Research, Vol. 30 No. 3, pp. 354-377.

Lee, I. and Arcodia, C. (2011), "The role of regional food festivals for destination branding", International Journal of Tourism Research, Vol. 13 No. 4, pp. 355-367, doi: 10.1002/jtr.852.

Lee, Y.K., Lee, C.K., Lee, S.K. and Babin, B.J. (2008), "Festivalscapes and patrons' emotions, satisfaction, and loyalty", Journal of Business Research, Vol. 61 No. 1, pp. 56-64, doi: 10.1016/j. jbusres.2006.05.009.

Lee, S., Bruwer, J. and Song, H. (2017a), "Experiential and involvement effects on the Korean wine tourist's decision-making process", Current Issues in Tourism, Vol. 20 No. 12, pp. 1215-1231.

Lee, W., Sung, H., Suh, E. and Zhao, J. (2017b), "The effects of festival attendees' experiential values and satisfaction on re-visit intention to the destination", International Journal of Contemporary Hospitality Management, Vol. 29 No. 3, pp. 1005-1027.

Long, L. (2004), Culinary Tourism, The University Press of Kentucky, Lexington.

Lopez-Guzman, T., Hernandez-Mogollon, J.M. and Di Clemente, E. (2014), "Gastronomic tourism as an engine for local and regional development”, Regional and Sectoral Economic Studies, Vol. 14 No. 1, pp. 95-104.

Malhotra, N.K., Nunan, D. and Birks, D.F. (2017), Marketing Research: an Applied Approach, Pearson Education.

Marchini, A., Riganelli, C. and Diotallevi, F. (2015), “The success factors of food events: the case study of umbrian extra virgin olive oil", Journal of Food Products Marketing, Vol. 22 No. 2, pp. 147-167, doi: 10.1080/10454446.2014.1000432.

Mariani, M.M., Buhalis, D., Longhi, C. and Vitouladiti, O. (2014), "Managing change in tourism destinations: key issues and current trends", Journal of Destination Marketing and Management, Vol. 2 No. 4, pp. 269-272.

Mariani, M.M. and Giorgio, L. (2017), "The 'Pink Night' festival revisited: meta-events and the role of destination partnerships in staging event tourism”, Annals of Tourism Research, Vol. 62, pp. 89-109. 
$\mathrm{BFJ}$

124,2

Mason, M.C. and Paggiaro, A. (2009), "Celebrating local products: the role of food events", Journal of Foodservice Business Research, Vol. 12 No. 4, pp. 364-383, doi: 10.1080/15378020903344323.

Mason, M.C. and Paggiaro, A. (2012), "Investigating the role of festivalscape in culinary tourism: the case of food and wine events", Tourism Management, Vol. 33 No. 6, pp. 1329-1336, doi: 10.1016/ j.tourman.2011.12.016.

Mason, P., Augustyn, M. and Seakhoa-King, A. (2010), "Exploratory study in tourism: designing an initial, qualitative phase of sequenced, mixed methods research", International Journal of Tourism Research, Vol. 12 No. 5, pp. 432-448.

Meretse, A.R., Mykletun, R.J. and Einarsen, K. (2015), "Participants' benefits from visiting a food festival - the case of the Stavanger food festival (Gladmatfestivalen)", Scandinavian Journal of Hospitality and Tourism, Vol. 16 No. 2, pp. 208-224. doi: 10.1080/15022250.2015.1108865.

Nordic Council of Ministers (2008), "New nordic cuisine", available at: http://norden.diva-portal.org/ smash/get/diva2:701317/FULLTEXT01.pdf.

OECD (2012), Food and the Tourism Experience: the OECD-Korea Workshop, OECD Studies on Tourism, OECD Publishing, Paris. doi: 10.1787/9789264171923-en.

Okumus, B., Okumus, F. and McKercher, B. (2007), "Incorporating local and international cuisines in the marketing of tourism destinations: the cases of Hong Kong and Turkey", Tourism Management, Vol. 28 No. 1, pp. 253-261.

Pizzichini, L., Temperini, V. and Gregori, G.L. (2020), "Place branding and local food souvenirs: the ethical attributes of national parks' brands", Journal of Place Management and Development, Vol. 13 No. 2, pp. 163-175, doi: 10.1108/JPMD-06-2019-0043.

Richards, G. (2003), "Gastronomy: an essential ingredient in tourism production and consumption?", Hjalager, A.M. and Richards, G. (Eds), Tourism and Gastronomy, Routledge, London, pp. 17-34.

Riley, M. (2005), "Food and beverage management: a review of change", International Journal of Contemporary Hospitality Management, Vol. 17 No. 1, pp. 88-93, doi: 10.1108/09596110510577707.

Rinaldi, C. (2017), "Food and gastronomy for sustainable place development: a multidisciplinary analysis of different theoretical approaches”, Sustainability, Vol. 9 No. 10, p. 1748, doi: 10.3390/ su9101748.

Robinson, R.N.S. and Clifford, C. (2012), "Authenticity and festival foodservice experiences", Annals of Tourism Research, Vol. 39 No. 2, pp. 571-600, doi: 10.1016/j.annals.2011.06.007.

Robinson, R.N.S. and Getz, D. (2014), "Profiling potential food tourists: an Australian study", British Food Journal, Vol. 116 No. 4, pp. 690-706, doi: 10.1108/BFJ-02-2012-0030.

Salvador, R., Simões, A. and Soares, C.G. (2015), "Features of the European maritime clusters", paper presented at the 55th Congress of the European Regional Science Association: "World Renaissance: Changing Roles for People and Places”, August, Lisbon, Portugal, available at: https://www.econstor.eu/bitstream/10419/124674/1/ERSA2015_00666.pdf.

Santini, C., Cavicchi, A. and Belletti, E. (2013), "Preserving the authenticity of food and wine festivals: the case of Italy", Il Capitale Culturale. Studies on the Value of Cultural Heritage, Vol. 8, pp. 251-271, doi: 10.13138/2039-2362/558.

Sarantakos, S. (2012), Social Research, 4th ed., Red Globe Press, Springer Nature, London.

Scarpato, R. (2002), "Gastronomy as a tourist product: the perspective of gastronomy studies", in Hjalager, A.M. and Richards, G. (Eds), Tourism and Gastronomy, Routledge, London, pp. 51-70.

Simeon, M.I. and Buonincontri, P. (2011), "Cultural event as a territorial marketing tool: the case of the Ravello Festival on the Italian Amalfi Coast", Journal of Hospitality Marketing Management, Vol. 20 Nos 3-4, pp. 385-406.

Sims, R. (2009), "Food, place and authenticity: local food and the sustainable tourism experience", Journal of Sustainable Tourism, Vol. 17 No. 3, pp. 321-336, doi: 10.1080/09669580802359293.

Smith, S. and Costello, C. (2009), "Culinary tourism: satisfaction with a culinary event utilizing importance-performance grid analysis", Journal of Vacation Marketing, Vol. 15 No. 2, pp. 99-110, doi: 10.1177/1356766708100818. 
Sthapit, E. and Coudounaris, D.N. (2018), "Memorable tourism experiences: antecedents and outcomes", Scandinavian Journal of Hospitality and Tourism, Vol. 18 No. 1, pp. 72-94.

Tikkanen, I. (2007), "Maslow's hierarchy and food tourism in Finland: five cases", British Food Journal, Vol. 109 No. 9, pp. 721-734, doi: 10.1108/00070700710780698.

Van Niekerk, M. (2017), "Contemporary issues in events, festivals and destination management", International Journal of Contemporary Hospitality Management, Vol. 29 No. 3, pp. 842-847, doi: 10.1108/IJCHM-01-2017-0031.

Van Niekerk, M. and Getz, D. (2016), "The identification and differentiation of festival stakeholders", Event Management, Vol. 20 No. 3, pp. 419-431, doi: 10.3727/152599516X14682560744910.

Xiao, H. and Smith, S.L.J. (2006), "Case studies in tourism research: a state-of-the-art analysis", Tourism Management, Vol. 27 No. 5, pp. 738-749, doi: 10.1016/j.tourman.2005.11.002.

Yang, F.X., Wong, I.A., Tan, X.S. and Wu, D.C.W. (2020), "The role of food festivals in branding culinary destinations", Tourism Management Perspectives, Vol. 34, p. 100671.

Yin, R.K. (1994), "Discovering the future of the case study. Method in evaluation research", Evaluation Practice, Vol. 15 No. 3, pp. 283-290.

Yin, R.K. (2017), Case Study Research and Applications: Design and Methods, 6th ed., Sage Publications, Thousand Oaks, CA.

Yuan, J. and Jang, S. (2008), "The effects of quality and satisfaction on awareness and behavioral intentions: exploring the role of a wine festival", Journal of Travel Research, Vol. 46 No. 3, pp. 279-288, doi: 10.1177/0047287507308322.

\section{Further reading}

Cohen, E. and Avieli, N. (2004), "Food in tourism", Annals of Tourism Research, Vol. 31 No. 4, pp. 755-778, doi: 10.1016/j.annals.2004.02.003.

Getz, D. and Brown, G. (2006), "Critical success factors for wine tourism regions: a demand analysis", Tourism Management, Vol. 27 No. 1, pp. 146-158, doi: 10.1016/j.tourman.2004.08.002.

Lau, C. and Li, Y. (2019), "Analyzing the effects of an urban food festival: a place theory approach", Annals of Tourism Research, Vol. 74, pp. 43-55, doi: 10.1016/j.annals.2018.10.004.

Mossberg, L. (2007), "A marketing approach to the tourist experience", Scandinavian Journal of Hospitality and Tourism, Vol. 7 No. 1, pp. 59-74, doi: 10.1080/15022250701231915.

Novello, S. and Fernandez, P.M. (2014), "The influence of event authenticity and quality attributes on behavioral intentions", Journal of Hospitality and Tourism Research, Vol. 40 No. 6, pp. 685-714, doi: $10.1177 / 1096348013515914$.

Updhyay, Y. and Sharma, D. (2014), "Culinary preferences of foreign tourists in India", Journal of Vacation Marketing, Vol. 20 No. 1, pp. 29-39, doi: 10.1177/1356766713486143.

Yoon, Y.S., Lee, J.S. and Lee, C.K. (2010), “Measuring festival quality and value affecting visitors' satisfaction and loyalty using a structural approach", International Journal of Hospitality Management, Vol. 29 No. 2, pp. 335-342, doi: 10.1016/j.ijhm.2009.10.002.

\section{Corresponding author}

Lucia Pizzichini can be contacted at: 1.pizzichini@staff.univpm.it

For instructions on how to order reprints of this article, please visit our website:

www.emeraldgrouppublishing.com/licensing/reprints.htm

Or contact us for further details: permissions@emeraldinsight.com 